\title{
Didactic sequence for the teaching of vitiviniculture with a cts approach in the gastronomy technology course
}

DOI: $10.46932 / \mathrm{sfjdv2n2-107}$

Received in: March 1st, 2021

Accepted in: May 30th, 2021

\section{Regina Coeli C. Perrotta}

Master- Cruzeiro do Sul University - Centro Universitário Nossa Senhora do Patrocínio (CEUNSP) Full Address: CEUNSP - R. do Patrocínio, 716- Itu- SP,13300-200

E-mail: reginaperrotta@globo.com

\section{Carmem Lúcia Costa Amaral}

Doctor- São Paulo University - Cruzeiro do Sul University (UNCSUL)

Full Address: UNCSUL - R. Galvão Bueno, 868- São Paulo- SP,01506000

E-mail:carmem.amaral@cruzeiro do sul.edu.br

\section{Regina Coeli C. Perrotta}

Master- Cruzeiro do Sul University - Centro Universitário Nossa Senhora do Patrocínio (CEUNSP) Full Address: CEUNSP - R. do Patrocínio, 716- Itu- SP,13300-200

E-mail: reginaperrotta@globo.com

\section{Carmem Lúcia Costa Amaral}

Doctor- São Paulo University - Cruzeiro do Sul University (UNCSUL)

Full Address: UNCSUL - R. Galvão Bueno, 868- São Paulo- SP,01506000

E-mail:carmem.amaral@cruzeiro do sul.edu.br,

\begin{abstract}
To generate an analytical position in science education, it is recommended that the teacher involve students in what will be approached, combining social and technological reality, contributing to decision making as a citizen and critical participation in society, parameters defended by the CTS movement (Science, Technology and Society). Considering these assumptions, an SD (didactic sequence) was adopted for Vitiviniculture in the discipline Introduction to Oenology guided by the following questions: How to establish the existing relationships between social, technological and environmental issues as to the production and promotion of wine, properly training these individuals to develop their judging capacity? Such questioning arose mainly because these students, in their professional practice, promote a drink that can bring social and environmental benefits and damages, and that contains chemical substances that are not described on wine labels. Therefore, the objective was to analyze the influence of a didactic sequence aimed at Vitiviniculture, verifying whether the students perceived the CTS interaction in the manufacture and use of wine. The research subjects were 35 students from the Nossa Senhora do Patrocínio University Center (Itu- SP Brazil) of the Gastronomy Technology Course. As a methodological procedure, a qualitative approach was adopted and as data collection, a pre- and post-questionnaire with contextualized open and closed questions were used, and an SD on the cultivation of grapes, the manufacture of wine and the economic exploration of this product. During the SD the relationships between the social, technological and scientific contexts of Vitiviniculture were discussed with an emphasis on alcoholic fermentation, socio-environmental problems and analysis of wine labels. The results indicate citizen contribution, gain of knowledge regarding the theme and a greater understanding of the CTS relationship, as a result of this unique strategy.
\end{abstract}


Keywords: Science teaching, Didactic sequence, CTS, Vitiviniculture, Wine.

\section{INTRODUCTION}

The act of teaching has always taken place in social relationships, whether formally or not, making intellectual progression happen. In order to mediate information in conventional environments, such as in schools and in universities, the presence of the teacher is necessary, which is expected to promote learning where the two parties can interact and build a solid background that leads to a reflective act.

To generate such a reflective act, the teacher needs to involve the students in the content that is being approached, aligning the reality that surrounds them, and bringing forward situations and questions that stimulate their understanding and dedication. This direction is in line with the assumptions of the CTS (Science, Technology and Society) approach in education, which, according to Santos and Mortimer (2002), postulates the preparation of students for the exercise of citizenship as the central objective in the search for an understanding of the scientific contents in their social, technological and environmental context.

The inclusion of the CTS approach in the teaching practice contributes to assisting the student to make responsible decisions on issues involving Science and Technology in society and the environment. Among these issues are the production and promotion of wine, as its production requires scientific and technological knowledge for its improvement and at the same time its production generates waste that has consequences for the environment and the society. As a result, these issues must be addressed and discussed with gastronomy students so that they can adopt a critical posture both in terms of wine consumption and promotion so as to take a stand before wine producers. However, the following question is raised: How to establish the relationships between social, technological and environmental issues as to the production and promotion of wine, with a CTS focus, properly training these individuals to develop their judging capacity?

To answer this question, a didactic sequence (SD) with a CTS focus was developed with students from the Technological Course in Gastronomy at the Centro Universitário Nossa Senhora do Patrocínio (CEUNSP), in the city of Itu, at the state of São Paulo, Brazil. The SD was applied in the discipline of Introduction to Oenology and approached the theme of Vitiviniculture.

The discipline of Introduction to Oenology, in addition to providing general knowledge about the history of wine in Brazil and in the world, was devised so that students could be given basic notions of Vitiviniculture, through the acquisition of information that leads to the understanding how the production of this drink occurs, from the planting to the final product, as well as the introduction of this drink in the 
menus, proposing ways to harmonize wine with food, and glancing into the environmental aspects that involve the wine industry.

Given the need for new technologies aimed at vitiviniculture that reduce environmental impacts and the fact that students of the Technology Courses in Gastronomy, who besides studying it, also promote this drink, it is noted that there is a close relationship with the CTS assumptions. Thus, the objective of this study was to analyze the influence of SD, built based on the CTS assumptions, on the students' perception regarding the issues involving the relations of Science and Technology in wine production and its promotion in the society, and their awareness of environmental issues.

\section{THE CTS MOVEMENT}

The emergence of the CTS movement occurred in view of the worsening of environmental problems in the post-war period, the awareness of some intellectuals regarding ethical issues, the quality of life of industrialized society, the demand for popular participation in public decisions and fear and the frustration resulting from technological excesses (SANTOS, MORTIMER, 2002).

This emergence was due to some historical factors such as the Cold War and the Counterculture Movement of the 1960s, thus motivating, later, the transposition of the CTS movement into teaching, which has been establishing actions in different fields such as in research, in the formulation of public policies and of education programs (CHRISPINO et al., 2010).

According to Trivelato (1993), the purpose of the CTS movement in education resides in the question that when teaching Science, one must seek outstanding individuals with critical thinking as the outcome; the development of high-level cognitive skills; problem solving competence and the ability to make their own decisions while fully exercising citizenship. However, for Vázquez and Manassero (2012) this will only be achieved if scientific education includes everyone in a relevant way and if education is presented in a context for the society.

According to Garcia, Cerezo and Lopez (1996), as a result of the emergence of the CTSmovement, politicization occurred in the spheres of science and technology in several countries with curricular deployments in secondary and higher education. And such teaching, according to Santos (2010) aims to a logic and an axiological orientation towards the educational and cultural dimension. It does not confine science teaching to the academic status of the discipline, it bets on the Science focused on the citizen. It strives for Science and its other side, Technology, to penetrate ever more profoundly into our social daily life as an integral part of the cultural debates that address the current social issues.

In Brazil, discussions related to the CTS movement initially took place in the 1990s and with it, according to Zauith, Ogata and Hayashi (2011) innovations were brought to the school curriculum, as 
well as changes in the view of Science, allowing the individual to exercise citizenship and the ability to make rational and democratic decisions in civil society.

Therefore, following this path, it is assumed that it is possible to promote the construction of reasoned and contextualized knowledge, establishing the possibility of creating citizens with critical thinking, who arrive at responsible conclusions. Having the co-construction of knowledge and citizenship as one's objective is what is called citizen education, which encourages learning, thinking and harmonizing our interest with the collective interest, among others (SANTOS, 2010).

One of the ways of educating through science is to seek education that includes educational practices that favor this ideal, that allow the information mediator, in this case the teacher, to apply techniques that encourage the student to reason, and that, in addition to retaining what was conveyed, take a stand as to controversial issues such as those involving environmental, technological and social issues in Vitiviniculture.

\section{VITIVINICULTURE AND THE TECHNOLOGY COURSE IN GASTRONOMY}

Henderson and Rex (2012) define Viticulture as the cultivation of vineyards and wine production. For other authors, as described by Mendes, Quinzani and Perrotta (2015), vitiviniculture refers to the cultivation of the vine, the grape harvesting, the alcoholic fermentation, and the maturation of the wine, all of which can also be defined, as the process that involves the cultivation of the grape and the wine making process, combined with the economic exploration of this product.

Franco (2001) reports that mythology and ancient symbolism attributed regenerative powers to wine, as well as the ability to bring man closer to divinity and that societies see staple food as sacred items, and that in the case of the Christian world, these would be bread, wine, and the olive. In this case, wine is considered to be food. However, Reis (2015) points out that despite some arguments justifying that drinks are considered to be food, from the political and market viewpoints, there are no clear indications in this regard. In this study we will refer to wine as a drink and not as food.

It can be seen, therefore, that the focus of the gastronomy course is not limited to gastronomic productions and there is the responsibility to train professionals in skills to understand, analyze, suggest, and serve alcoholic beverages that pair with dishes (REIS, 2015).

The fact is that wine is often consumed with food and for this reason its method of manufacture, grape cultivation and possibilities of use and consumption are covered in the Gastronomy Technology Course, thus reiterating the importance of this study. 


\section{METHODOLOGY}

This methodology adopted a qualitative approach, and the data collection included a pre- and a post-questionnaire, an SD involving the contents ofgrape cultivation, wine making, economic exploration of this product, and the CTS relationships involved in these contents. The questionnaires were prepared with contextualized open and closed questions in order to assess the students' perception of the CTS relationships involved in vitiviniculture. The time interval between the application of two questionnaires was approximately 60 days, according to the university calendar.

The SD was developed and applied in a class comprising 35 students of the Gastronomy Technology Course offered in the morning, in the discipline of Introduction to Oenology. In order to better understand the circumstances and develop the SD, Zabala's theoretical framework (1998) was used, which states that one of the instruments to differentiate the educational practice is the application of an SD as a teaching-learning strategy, and that it consists of a sequence of interconnected activities that are designed to teach a certain content.

After the data collection and the completion of the SD, a qualitative analysis of the data was performed, where it was possible to identify categories of analysis in the discursive questions, based on the content analysis, which were divided into groups according to Bardin (2010). This work will present the results of the analysis of some of the questions of the questionnaires.

\section{ANALYSIS OF THE PRE- AND POST- QUESTIONNAIRE}

To better illustrate the contribution of SD in assisting the student in decision-making on issues involving the relations of Science and Technology in wine production, its promotion in society and its effects on the environment, the results of the pre- and post-questionnaires were analyzed together, except for the first question in the post-questionnaire which was modified, and therefore, was analyzed separately. Thus, we initially asked the students the definition of wine. For this question, a small text was presented (Box 1) so that they could identify the conceptual errors and explain them.

Box 1: Question 1 of the post-questionnaire

1) (VIANNA JUNIOR, D .; SANTOS, JI; LUCKY, J., 2015- adapted) Read the text below:

Wine is a natural drink. The crushed grapes are the must. A microorganism that forms on the skin of the grape, called yeast, converts the sugar of the grape into ethyl alcohol and carbon dioxide. This phenomenon is called alcoholic fermentation.

Do you agree with all previous statements? ( ) Yes. ( ) No. Why?

$$
\text { Source: Authors }
$$

As we can see in Box 1, the first sentence of the text says that wine is a natural drink. For that sentence 21 students did not agree; 13 agreed and 1 student did not respond. Among the 21 students who 
did not consider wine to be a natural drink, 19 justified their choice. The justifications for this statement were divided into groups and are shown in Graph 1.

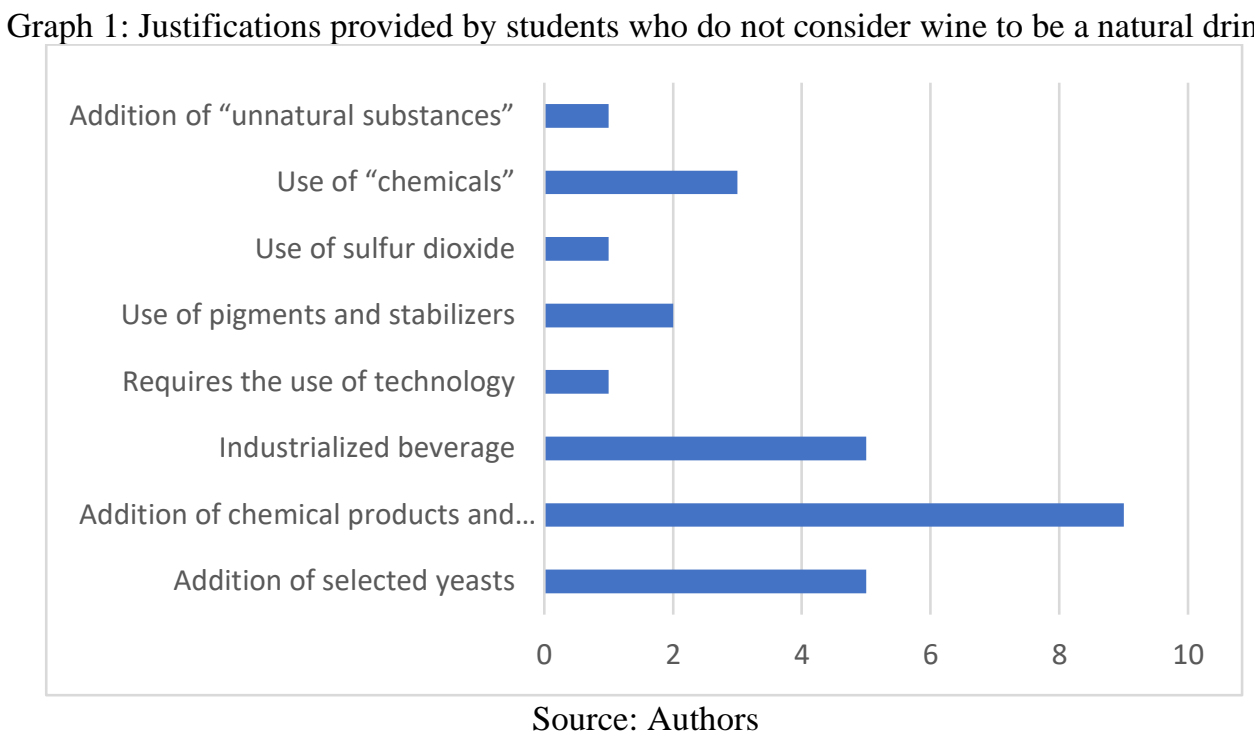

This graph shows the variation in the justifications, with a higher incidence of responses in addition to the fact of the addition of chemical products, followed by the justification that the yeasts used are not from the skin of the grape itself, that is, they are selected and consequently added by humans and also because wine is an industrialized drink. Other responses referred to facts such as: "Use of chemicals", demand for technology for its manufacture, use of pigments and stabilizers, addition of sulfur dioxide and "unnatural substances".

In the text, students should recognize the process of alcoholic fermentation in wine production. The answers obtained showed that the majority (13 students) understood that wine production depends on yeasts and their choice depends, in turn, on humans when they select them and choose the technology that will be used for the alcoholic fermentation, making it clear that including and approaching CTS themes in science education with a critical perspective means broadening the view on the role of science and technology in society (SANTOS, 2007). Therefore, these discussions must involve values and attitudes, but they must be associated with the conceptual understanding of the themes related to these socioscientific aspects, as decision-making implies the understanding of scientific concepts related to the subject in question (SANTOS, 2007).

Question 2 aimed to diagnose the students' perception of the concept of terroir. Understanding this concept is important because in most gastronomy and wine books (targeting this public in question), its concept does not cover human handling and, consequently, the technologies that are used for the manufacture of wine, maintaining the romanticized idea that wine is a product of the soil, climate, grape 
species and topography alone. In this question, we ask the respondents to point out the variables that relate to the terroir. Graph 2 shows the students' responses.

Graph 2: Variables that relate to the terroir as chosen by the students.

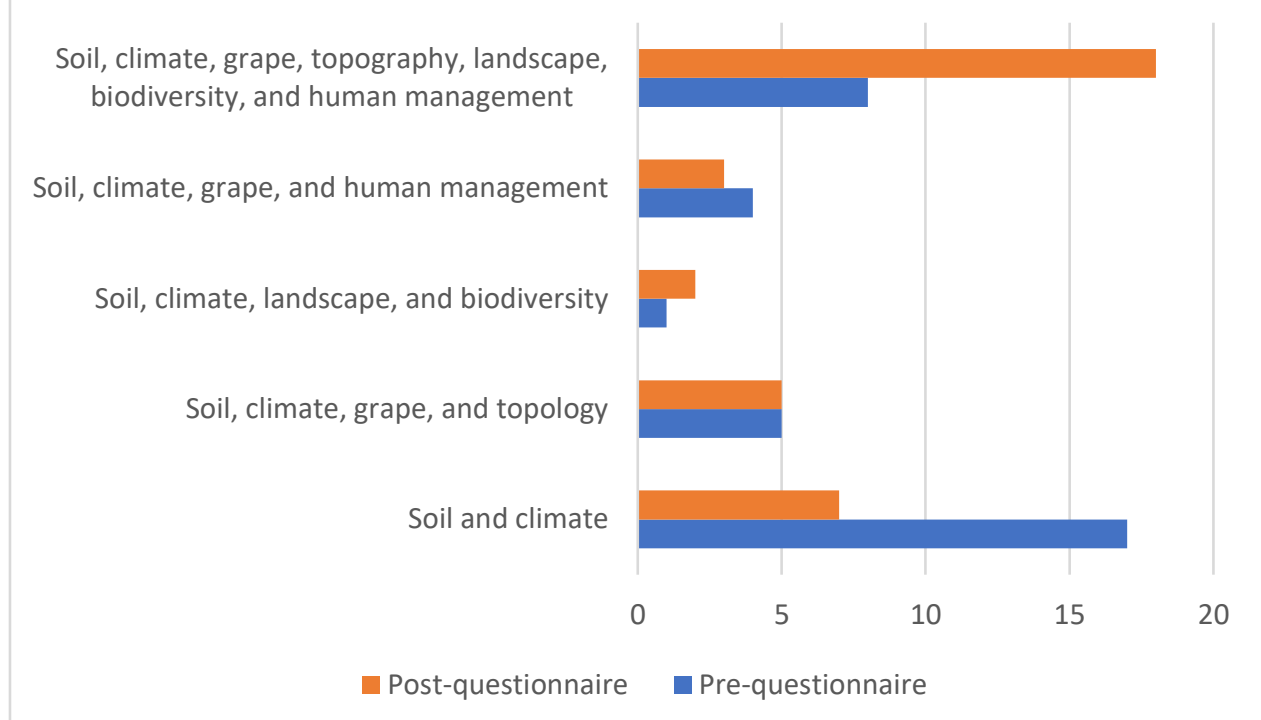

Source: Authors

As we can see in this graph, in the pre-questionnaire the majority (17 students) associated only the soil and the climate, as components of the terroir, however, after the SD this number dropped to 7, and they started to understand that other variables encompass the terroir. As for the inclusion of humans in the terroir, it was found that initially only 12 students out of the total respondents considered human management, whereas after the SD, 21 students considered human management as an integral part of the terroir, although still a significant share, refer to the soil and climate variables. The importance of this result for the CTS approach lies in the fact that for some it was already possible to establish the natural and human elements in the production of wine, realizing that there is human intervention and the use of technology in the production of the drink.

It is possible that students still associate the concept of terroir only to the climate and the soil because, as previously explained, many books on wines and foods, which are used as reference by students in the gastronomy course, present their concept unrelated to human management.

Question 3 intended to identify the students' perception of the social and environmental effects of wine production. In the pre-questionnaire, 16 students thought that the production and use of wines have positive social and environmental effects, 6 students said they would not know how to answer the question, 7 left it blank, 1 student identified negative aspects and 4 students pointed out both negative and positive aspects. One (1) student answered without making any association with the question (he explained how fermentation occurs). The frequency of the mentioned positive effects is shown in graph 3 . 
Graph 3: Positive effects of wine production on society and the environment as pointed out by students.

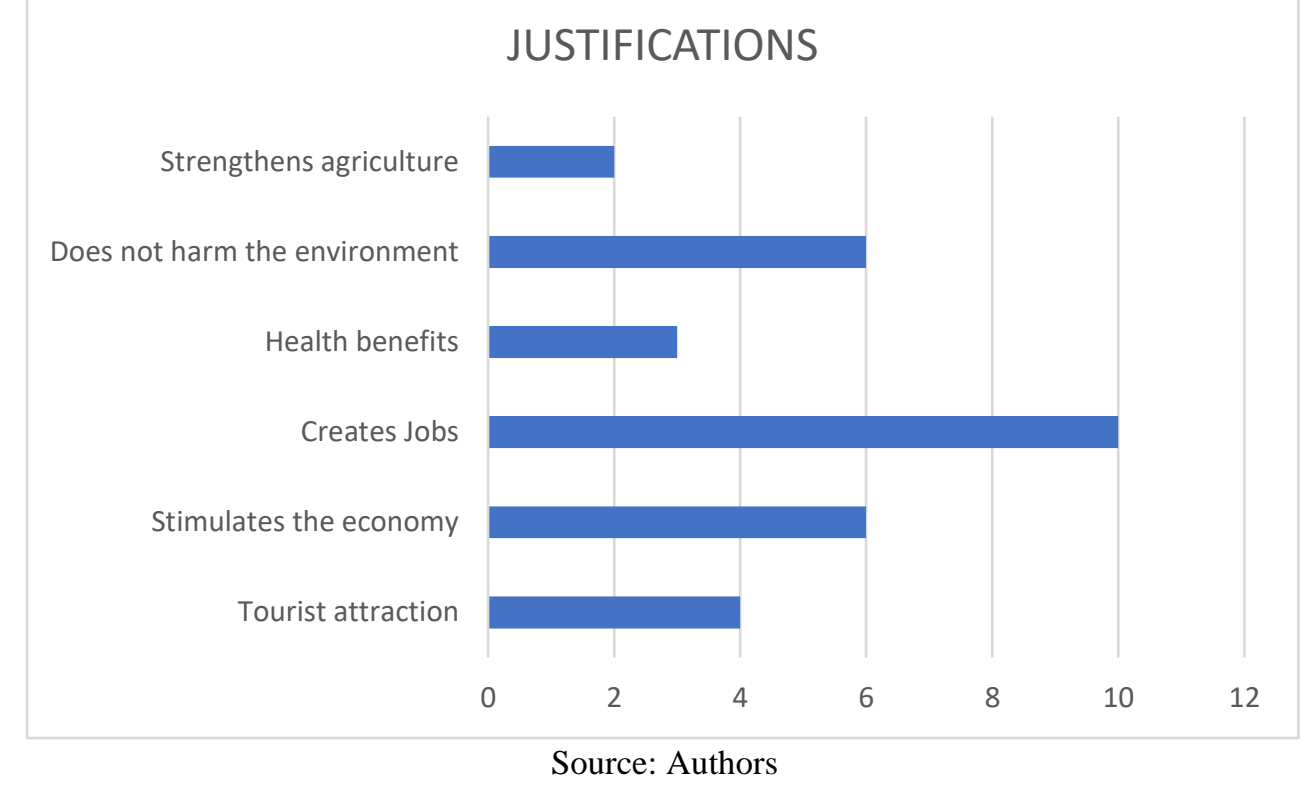

According to this graph, the most often mentioned positive effects were the generation of jobs, followed by the non-generation of damage to the environment, the stimulus of the economy, the representation of a tourist attraction, health benefits, and finally the strengthening of agriculture. Other aspects were also mentioned at least once in the students' responses, such as: favoring gastronomy, maintaining a food culture, creating new areas of professional activity, making people happy, among others.

As for the negative aspects, deforesting the environment was a fact mentioned; the non-generation of jobs since it is not craft wine, but rather, industrialized wine; excessive alcohol consumption and the dangers of drinking and driving. It is worth mentioning that when they say that the negative aspect is the non-generation of jobs due to the fact that it is an industrialized production, it can be seen in this impression that the technology for these students is associated with the use of machines that lead to the replacement of humans, giving the idea that machines compete with individuals. This idea shows that technology is still seen from its technical aspect and is often reduced to it, with its organizational and cultural aspects ignored, demonstrating that it is dependent on the socio-political systems and the values of the cultural ideologies surrounding it (SANTOS; MORTIMER, 2002).

After the application of the SD, 18 students pointed out only negative aspects; 12 indicated positive and negative aspects; 2 identified positive aspects and 3 students did not answer the question. Among the positive effects, those most often mentioned were job creation (7 students) and economic activity (4 students), as can be seen in Graph 4. 
Graph 4: Positive social and environmental effects presented by students in the post-questionnaire.

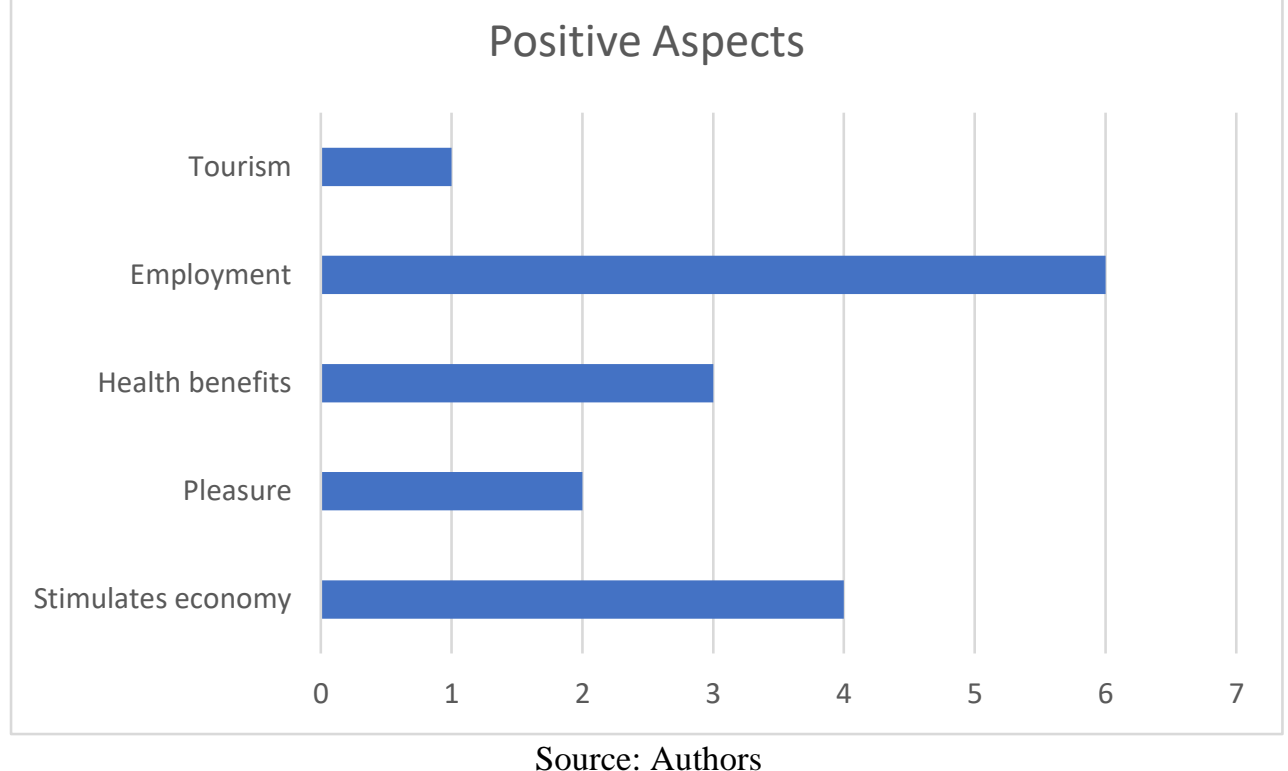

Source: Authors

In addition to the creation of jobs and the stimulus of the economy, the health benefits, the activities of tourism connected to this activity and the pleasure generated by the consumption of the beverage were also mentioned as advantages in the production and consumption of wine. As for the negative effects, 14 students identified the generation of waste in the environment and 18 students identified the excessive use of water in wine production (graph 5).

Graph 5: Negative social and environmental effects presented by students in the post-questionnaire.

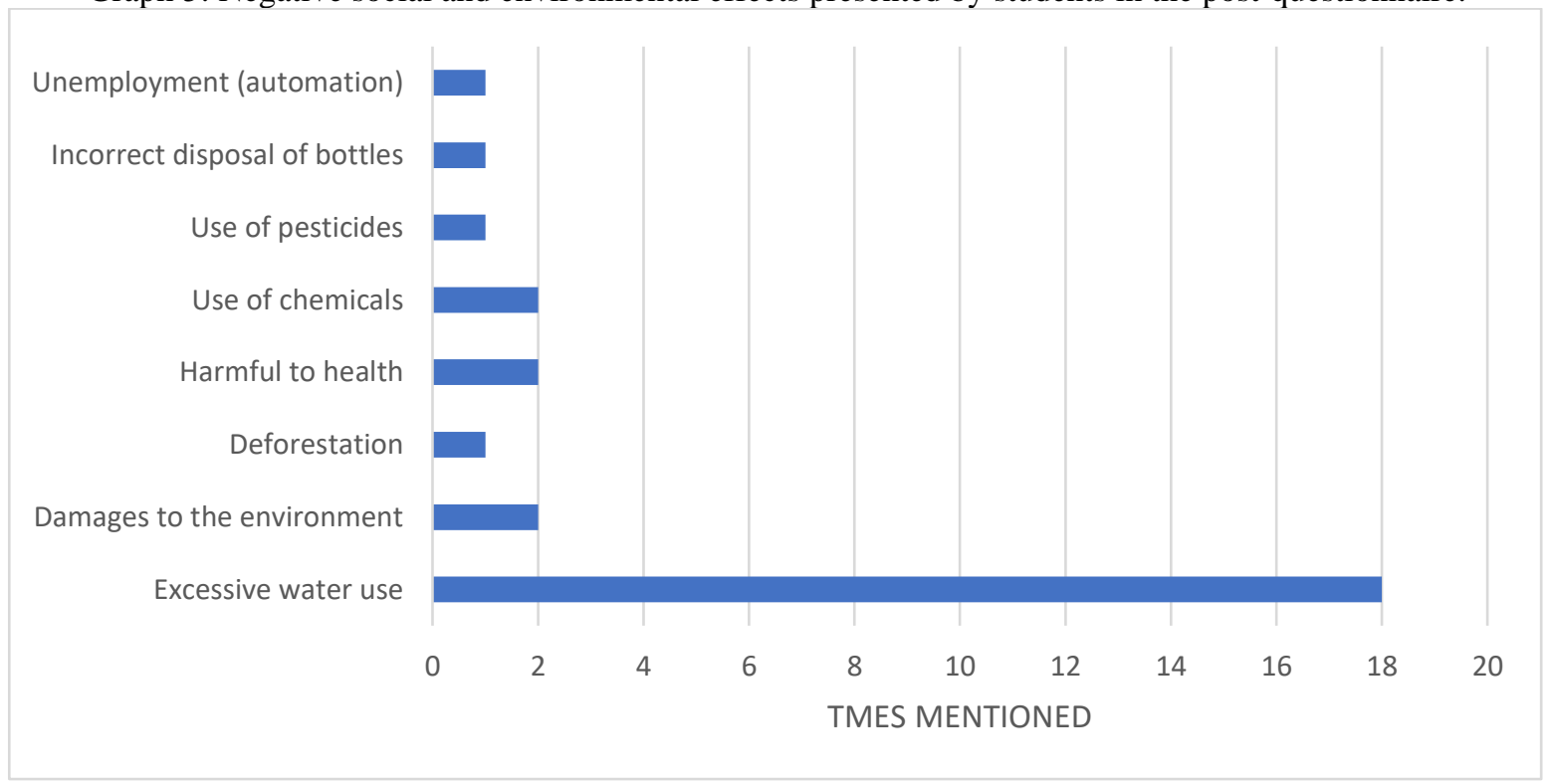

Source: Authors

These effects pointed out by the students show that most of those who identified negative aspects perceived the effect of wine production on the environment, and thus, these results corroborate with the 
assumptions of Freitas and Marques (2017, p. 226), since they say that socio-environmental issues are legitimate concerns that have growing social interest, demanding a complex understanding of the relationships among Science, Technology, Society, and the Environment.

All of these aspects were addressed in the classroom during the application of the SD, however, the issue of incorrect disposal of glass bottles and unemployment due to the automation of most of the process, were not discussed during the development of the SD.

In addition to the questions above, a question referring to professional practice was included in the post-questionnaire (Box 2), trying to combine the theory taught with the reality that the students face and will face in their work environment.

Box 2: Question added to the post-questionnaire.

Analyze possible solutions to meet the challenge that you will face in your professional practice when proposing food-wine combinations, promoting a drink that both causes harm and brings benefits, and contains chemicals that are not described on the labels.

Source: Authors

The answers to this question can be seen in Graph 6 .

Graph 6: Possible solutions to meet the challenge of professional practice

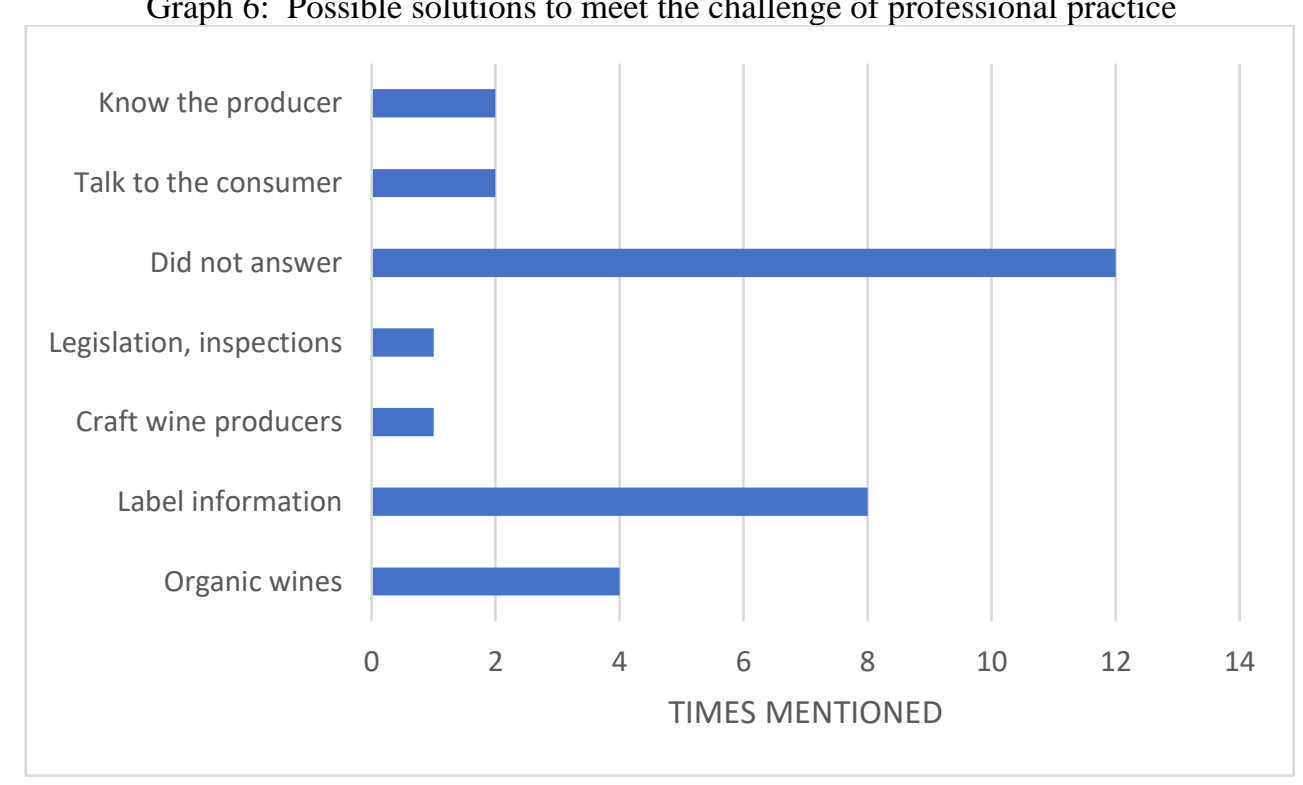

Source: Authors

In this graph we can see that 17 students understood that a possible solution to the challenge may come from themselves, since they suggested the option for organic wines, seek information on the labels, meet the producers, talk to the consumer beforehand and choose craft wine producers when suggesting 
wine-food combinations during their professional practice, thus recognizing themselves in this group, which can promote the citizen attitude advocated by the CTS movement.

What was also relevant in the result of this question was the significant number of students (12), who did not answer the question, which can be interpreted as a position of doubt in the face of the proposed situation. However, only one student admitted in writing that he did not know the solution, because it was, in his own words, "a difficult situation". This omission of answers and doubts when answering the question may have originated from the romanticized view of wine that many may share, which, despite the application of the SD, had not been deconstructed.

Only 1 student transferred the responsibility for the resolution of the issue by proposing more laws and inspections, which can show that, in his view, this is a problem that must be resolved by the legislative and judiciary branches, not identifying in ordinary citizens the power to reverse this reality in his social context.

However, some responses were also surprising due to the fact that they were not consistent with what was expected, among them, the one that specified that the solution is to drink wine with water, another that stated that one should serve and combine wine and food without asking questions, and a last one that only said that "most people are unaware of the harm that wine can cause".

These results show that students do not yet have sufficient subsidies to solve this problem, pointing to the need for the SD to be reviewed to expand the discussions on this subject.

\section{FINAL CONSIDERATIONS}

In view of the teaching context, it is recommended that the teachers should be on the lookout for alternatives so that their educational practice can be improved and enhanced. When developing an SD focused on the introduction of oenology and vitiviniculture studies addressing social, cultural, technological, and environmental aspects for the Gastronomy course, an attempt was made to boost the development and the learning, giving rise to a critical, assertive and citizen training, and mainly, with the internalization of the content.

Therefore, the teacher must keep in mind the value of the pedagogical action, always considering the subjects of this action as fundamental, in this case the students, so that the contents can be retained and internalized. Therefore, the proposed SD acted as a support in the formation of citizens aware of their role in society, with regard to the teaching of Vitiviniculture.

However, it is worth mentioning that changes and adaptations must be made, since the educational contexts are not repeated, and that even after the application of the SD, the students' doubts persisted as to the position that should be adopted in their professional practice. However, the results indicate citizen 
contribution, gain of knowledge regarding the theme and a greater understanding of the CTS relationship, as a result of the specific strategy. 


\section{REFERENCES}

BARDIN, L. Análise de Conteúdo. Portugal: Asa, 2010.

CHRISPINO, A. et. al. As crenças de profissionais e alunos sobre tecnologia. In: ROIG, A.B. et al. Ciência, Tecnología y Sociedad en Iberoamerica: uma evaluación de la comprensión de la naturaleza de ciencia y tecnologia. Madrid: Centro de Altos Estudos Universitários de la OEI, 2010.

FRANCO, A. De caçador a gourmet. Uma história da gastronomia. São Paulo: Editora Senac São Paulo, 2001.

FREITAS, N.M.S.; MARQUES, C.A. Abordagens sobre sustentabilidade no ensino CTS: educando para a consideração do amanhã. Educar em Revista, n.65, p.219-235, 2017.

HENDERSON, J.P.; REX, D. Sobre vinhos. Tradução de Iara Fino. São Paulo: Cengage Learning, 2012.

MENDES, B.C; QUINZANI, S.P.; PERROTTA, R.C.C. Processo de Regionalização Gastronômica: Uma Análise do Vale dos Vinhedos. In: II COLÓQUIO INTERNACIONAL DE PESQUISA E PRÁTICAS EM TURISMO. Anais do IX Congresso Brasileiro de Turismo Rural. Joinville: Instituto Federal de Ensino e Tecnologia de São Paulo, Campos do Jordão, 2015.

REIS, J.T. Bebidas e hospitalidade: produção científica no Brasil (2004-2012). 2015. 169f. Dissertação de Mestrado em Hospitalidade- Universidade Anhembi Morumbi, São Paulo, 2015.

SANTOS, M.E.N.V.M. A dimensão CTS do ensino das Ciências: fundamentos, contextos e desafios. In: MACIEL, M.D; AMARAL, C.L.; GUAZZELLI, I.R.B. (Org.). Ciência, Tecnologia e Sociedade. São Paulo: Terracota, 2010. p. 71-91.

SANTOS, W.L.P; MORTIMER, E.F. Uma análise de pressupostos teóricos da abordagem C-T-S (Ciência- Tecnologia - Sociedade) no contexto da educação brasileira. ENSAIO - Pesquisa em Educação em Ciências, v.2, n.2, dez.2002.

TRIVELATO, S.L.F. Ciência/tecnologia/sociedade: mudanças curriculares e formação de professores. 1993.Tese (Doutorado) - Universidade de São Paulo, São Paulo, 1993.

VÁZQUEZ, A.; MANASSERO-MAS, M.A. La selección de contenidos para enseñar naturaleza de la ciencia y tecnologia (parte 1): uma revisión de las aportaciones de la investigación didática. Revista Eureka sobre Enseñanza de las Ciencias, v. 9, n. 1, p.2-31,2012.

VIANNA JUNIOR, D; SANTOS, J.I.; LUCKI, J. Conheça vinhos. São Paulo: Editora Senac São Paulo,2015.

ZABALA, A. A prática educativa: como ensinar. Porto Alegre: Artmed,1998. 